\title{
Panel Researching in Study of the Competitive Environment in Clothing Market
}

Hakimov Ziyodulla Ahmadovich*

Department of Management, Taskent State University of Economics, TTashkent, Uzbekistan

\begin{abstract}
Satisfaction of demand to necessary products for society life is the important problem of each state and a basis of definition of a standard of well-being of the population. The analysis of a condition of the market of clothes and definition of strategic targets on perspective changes are very much pressing questions. In given article possibilities of use of a method of panel research are considered at an estimation of the market of ready-to-wear clothes and its changes.
\end{abstract}

Keywords: Assortment; Household; Marketing; Market of clothes; Marketing research; Panel research; Segmentation family; Wardrobe of family

\section{Introduction}

In the formation of a competitive environment in the light industry market, the key factor is the structure and width of the assortment. Many scientists conducted research on problems in determining the range of strategic goals, including: an analysis of A Ansoff's matrix "commodity-market", D.Abell's matrix of the "center" of the $\mathrm{ABC}$ model, XYZ, the "Marcona" model, the "Dibba-Simkin" method. There are a number of scientific studies on the competitiveness of the assortment of light industry goods [1-11]. In these scientific researches methods of management of formation of assortment of the enterprises are reflected. Theoretical and practical aspects and methodological foundations. The problems of assortment policy development for light industry goods were investigated [12-14].

The issues of household research and the formation of demand have been widely studied in the scientific works of the honorable Russian worker of professional education, the scientist Burdenko [15]. It scientifically proves that the basis for shaping the demand for light industry products are income, seasonality of fashion, age and gender categories.

In our study, the subject of study is researching the state of competition in the light industry goods market and the formation of the assortment strategy of local enterprises, the panel method is used in the study.

\section{Method}

The method of panel research is one of the most widespread methods among marketing researches. Panel research is a data gathering from the selected respondents [16] from house economy by repeating interrogations in intervals where accurately defined duration of time are. Often term the 'panel' is used as equivalent with the term repeated research. The panel consists of sample of respondents, usually households which agree to give the information with certain intervals throughout the long period of time [17].

Panel research respondents would be compensated by organization leading it and they would be rewarded with various means, for example, gifts, certain amount of money, information and others. Investigation of families and their members' wardrobe assortment and its content gives great chance to assess consumers market. Therefore it is appropriate to use panel research in order to study consumers' wardrobe.
Household is considered as panel research participants. Householdis the group of people who run household and live in a certain address, by combining their income fully or partly [17]. Observation is leaded by interviewer [18]. Results of research could be wrong, unless the chosen participants of households are rewarded.

Due to panel research, the formation of wardrobe assortment of consumer's could be studied and used in practice, widely. In addition it helps to study the proportion of competent in assortment, and analyze the various aspects of consumer segments according to the assortment.

For panel research, households would be given daily form so, as to record research results. Moreover, nowadays daily media panel research is becoming popular. As online-forms are being used widely, they are giving great opportunity to define during the purchase process [19]. So that to depict the form's information we focused, on clothes of families that have accumulated during a whole year and the forms have collected in final month (December) of the year. During is process respondents fulfilled the forms with the data about the amount of apparels which have been included to their wardrobe during the year.

\section{Results and Discussions}

Usually the outcome of research gives information that is beneficial to study the impact of socio-financial course on living standards of population and improve well-being of nation, developed consumer commodities market, to take additional measures to form basket of goods [19].

Tables 1 and 2 depict the questionnaire that we have conducted for Panel research. It consists of two parts, the first gives information about family and its member's, also special characteristics about family member's segmentation. In the second part, there is the number of clothes of each segment that have been included to the family wardrobe during the year that is marked with special signs.

*Corresponding author: Hakimov Ziyodulla Ahmadovich, Senior Scientific Researcher, Department of Management, Taskent State University of Economics, Tashkent, Uzbekistan, Tel: +998939266610; E-mail: bekziyo84@mail.ru

Received August 03, 2017; Accepted August 16, 2017; Published August 23 2017

Citation: Ahmadovich HZ (2017) Panel Researching in Study of the Competitive Environment in Clothing Market. J Account Mark 6: 251. doi: 10.4172/21689601.1000251

Copyright: (c) 2017 Ahmadovich HZ. This is an open-access article distributed under the terms of the Creative Commons Attribution License, which permits unrestricted use, distribution, and reproduction in any medium, provided the original author and source are credited. 


\begin{tabular}{|l|l|l|l|l|}
\hline $\begin{array}{l}\text { Segmentation } \\
\text { criteria }\end{array}$ & $\begin{array}{l}\text { Segmentation of family members } \\
\text { number and their sex }\end{array}$ & $\begin{array}{l}\text { Segmentation family members by } \\
\text { age group }\end{array}$ & $\begin{array}{l}\text { Segmentation family } \\
\text { members by their income }\end{array}$ & $\begin{array}{l}\text { Segmentation family members by } \\
\text { their education degree and profession }\end{array}$ \\
\hline Segment aspects & $\begin{array}{l}\text { Men, women, } \\
\text { the number of men in the family, the } \\
\text { number of women in the family }\end{array}$ & $\begin{array}{l}\text { Pensioners (above 60), middle aged } \\
\text { (between 31-60), } \\
\text { adults (between 17-30), pupils (between } \\
8-16), \text { children (between 0-7) }\end{array}$ & Assessed by 5 quintal & $\begin{array}{l}\text { The number of members with higher } \\
\text { degree, the profession of head of family }\end{array}$ \\
\hline
\end{tabular}

Table 1: Determining the segment aspects of consumers [17].

\begin{tabular}{|c|c|c|c|c|}
\hline Name of apparels assortment & $\begin{array}{l}\text { Amount of purchase } \\
\text { (recorded during the year) }\end{array}$ & $\begin{array}{l}\text { Country of origin of the product } \\
\text { (main competitor-countries) }\end{array}$ & Shopping destinations & Price of purchase \\
\hline $\begin{array}{l}\text { Mass and elite assortment, hand- } \\
\text { made apparels, knitted garments, } \\
\text { underclothes, socks, shoes }\end{array}$ & Recorded in nature & $\begin{array}{l}\text { Uzbekistan, Russia, Kazakhstan, } \\
\text { Turkey, } \\
\text { China and other main competitors }\end{array}$ & $\begin{array}{l}\text { District city, in the countryside, supermarket, } \\
\text { department, store, shop, boutique, stores of } \\
\text { specialized firms, market complexes, tailors } \\
\text { and others }\end{array}$ & $\begin{array}{l}\text { Price of each ready- } \\
\text { made apparel would } \\
\text { be recorded. }\end{array}$ \\
\hline
\end{tabular}

Table 2: Assess the content of segment [19]

The purpose of Panel research by conducting the customers' readymade apparel wardrobe is given below:

1. Identifying the family's purchase of apparels and their changes in content;

2. Improving living standards of household, assessing the assortment content of purchasing clothes according to the changes in demand;

3. Estimate the ready-made clothes market according to the results of purchased goods assortment changes;

4. Intensify competitiveness of clothes' manufacturers and traders and corroborate their assortment policy, scientifically in the future.

In the questionnaire given to respondents, all family members make a record of clothes, which they have included to their wardrobe during the year. Outcome of each questionnaire is being attached to the program Excel and SPSS statistical program. From the forms given to the families results recorded in Table 3 .

Big changes have not been noticed in family and in its members' content. The amount of purchase by families' segment group is illustrated in Figure 1. There have been assessed the amount of purchased apparels by family members and changes during year 20122014, the proportion of competitors.

The purchase of ready-made clothes percentage of our national products among old-aged in families is high (women 54\% and 56\%, men $69 \%$ and $69 \%$ in 2012 and 2014, respectively). The demand of elderly people for national clothes (such as oriental robes) is increasing due to hygienic and climate conditions. In addition, they are actively, participating in weddings, traditional ceremonies, which in turn brings to high need for modern clothes(suits, coats) and they are purchasing clothes made in foreign countries.

Being considered the most attractive segment (in terms of purchase amount) adults' apparel share, made in Uzbekistan is lower than oldaged (women 32-31\%, men 67-69\% in 2012 and 2014 respectively). Because manufacturers have to meet certain conditions of this segment, its percentage remains low. On the contrary, there is higher need for men's finished apparel. As the main assortment of men's garment consists of coats, suits and shirts, they are not so sensible to fashion changes. In addition, there is being formed demand for national garments of women, as the main part of women in this segment prefers clothes offered by family businesspersons and in many cases of imported apparels do not meet their figures' specials needs.

The youth is regard as an insistent segment and show high level of

\begin{tabular}{|c|c|c|c|c|}
\hline $\begin{array}{c}\text { Age group of family } \\
\text { members }\end{array}$ & $\begin{array}{c}\text { Year } \\
\mathbf{2 0 1 2}\end{array}$ & $\begin{array}{c}\text { In percentage } \\
\mathbf{( \% )}\end{array}$ & $\begin{array}{c}\text { Year } \\
\mathbf{2 0 1 4}\end{array}$ & $\begin{array}{c}\text { In percentage } \\
\mathbf{( \% )}\end{array}$ \\
\hline The number of families & 500 & 100 & 500 & 100 \\
\hline $\begin{array}{c}\text { The number of family } \\
\text { members }\end{array}$ & 2790 & 100 & 2775 & 100 \\
\hline Above 60 & 146 & 5.2 & 150 & 5 \\
\hline Women & 95 & 3.4 & 109 & 4 \\
\hline Men & 50 & 1.8 & 41 & 1 \\
\hline Between 31-60 & 861 & 30.9 & 860 & 31 \\
\hline Men & 465 & 16.7 & 527 & 19 \\
\hline Women & 455 & 16.3 & 333 & 12 \\
\hline Between 17-30 & 620 & 22.2 & 749 & 27 \\
\hline Men & 270 & 9.7 & 333 & 12 \\
\hline Women & 350 & 12.5 & 416 & 15 \\
\hline Between 8-16 & 585 & 21.0 & 583 & 21 \\
\hline Between 0-7 & 520 & 18.6 & 433 & 16 \\
\hline
\end{tabular}

Table 3: Content analysis of family members (\%).

purchase. Because of limited assortment of goods offer, manufacturers are not able to meet an increasing insistent demand of consumer's, therefore their share in market still remains small compared to competitor (women $10 \%$ and $22 \%$, men $25 \%$ and $41 \%$, respectively). The youth group mainly consists of students, which is an important aspect of creating a demand. The difference of the segment is that there is huge impact of fashion and type of job. During certain years, clothes made in Uzbekistan and Turkey is seizing a market of Chinese producers. Another side that have consider is price and have produced massively.

In the group of student's the boys' apparel mainly consists of uniform and they are popular assortment, therefore China is still taking a leading place. Especially, major percentage of girls' uniforms, sportswear, blouses, cardigan, jumper and sweaters, dressing gowns and dresses is the manufactured in China. Interestingly, Uzbekistan's share in producing children's suits, trousers and shirts increased from $14-24 \%$ in two years, between years 2012-2014.

In the group of infant school attenders' the portion of Uzbekistan rose by $6 \%$ (from $11 \%$ to $17 \%$ ) during the period. The assortment of children clothes makes the major part of the group and share of China in this sector is decreasing, while that of Turkey, Korea and other countries (Iran, Pakistan) is getting higher. Following group is mainly formed by the choice of parents and unlike other groups; the considerable aspects are comfort in wearing, suitability of sizes and ornaments. Our manufacturers of children's ready-made apparels do not occupied enough place in market. It is noticeable that there is an increasing share of national clothes in the family's wardrobe.

There is a table, which have compiled according to segmentation of 


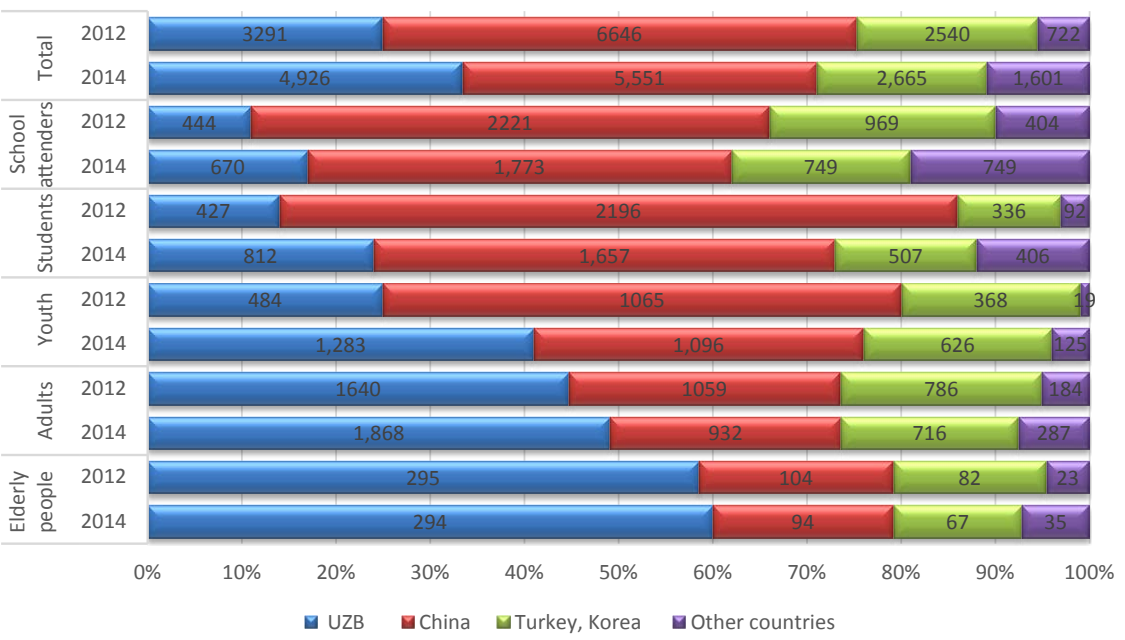

Figure 1: Condition of segment wardrobe of family members.

\begin{tabular}{|c|c|c|c|c|c|c|c|}
\hline $\begin{array}{l}\text { Age group of family } \\
\text { members }\end{array}$ & $\begin{array}{c}\text { Correlation with } \\
\text { price }\end{array}$ & $\begin{array}{c}\text { Consideration of } \\
\text { quality }\end{array}$ & $\begin{array}{c}\text { Matches for } \\
\text { fashion }\end{array}$ & $\begin{array}{c}\text { Impact of type of } \\
\text { profession }\end{array}$ & Hygienic impact & Others & Total \\
\hline Old-aged (above 60) & $* * *$ & $* * *$ & * & 0 & $* *$ & $* *$ & 11 \\
\hline Elderly (between 31-60) & $*$ & $* *$ & $* * *$ & ** & $* * *$ & $* * *$ & 14 \\
\hline Youth (between 17-30) & $* * *$ & $* \star *$ & $* \star *$ & * & $* * *$ & $* * *$ & 16 \\
\hline Students (between 8-16) & 0 & $* *$ & $* * *$ & $* * *$ & $*$ & * & 10 \\
\hline Children (between 0-7) & 0 & 0 & * & 0 & $* * *$ & & 4 \\
\hline
\end{tabular}

***: Strong impact; **: Medium impact; *: Little impact; 0: No impact.

Table 4: Influential factors in shaping family members wardrobe by age groups.

families by age groups considering factors, which affect purchase and changes in assortment content. As is illustrated in the Table 4, the most insistent segment is women aged 17-30 as well as men and women aged 31-60.

One more factor that exerts influence on families' purchase readymade apparels is social location of families. Dressing culture of family members is formed under the influence of householder and in turn, the factors that impact on assortment related to the education degree and profession. Obviously, the profession, life position determines family culture and range of clothes in the wardrobe is collect in accordance with them. Therefore, it is preferable to into account the type of activity of householder while grouping families. Because Uzbek mentality and oriental traditions are connected with dressing manners and families professions.

Therefore, we in the course of researches, first, have divided families into segments by their trades, and have established scale of purchase of ready-to-wear clothes (Table 5).

In the bought ready-to-wear clothes, during the research period, we have displayed a share of the countries-competitors through matrixes in Figures 2 and 3 by means of it we can estimate them. In the figures, one in all segments of families, the state China, only in families where the head of the family works abroad, and a share of Korea above has a high share. Figure shows matrix of a share of the countries in consumption of ready-to-wear clothes of segments by a trade of families for year 2012-2014.

In 2014 competitors in our internal market tried to get the place of Chinese products, share of Uzbekistan is increase in the account of industrial personnel, businessmen, military-men. In addition, share of products of Turkish and Korean origin has increased among the segment of individual businesspersons and entrepreneurs.

\begin{tabular}{|c|c|c|c|}
\hline Classification of families & Number of families & \multicolumn{2}{|c|}{ Total purchases } \\
\cline { 2 - 3 } & & Year 2012 & Year 2014 \\
\hline Teachers & 42 & 1407 & 1258 \\
\hline Doctors & 14 & 519 & 649 \\
\hline Clerks of state companies & 45 & 1038 & 1477 \\
\hline Entrepreneurs & 54 & 1391 & 1526 \\
\hline Farmers & 19 & 361 & 628 \\
\hline Dehkans & 89 & 961 & 1554 \\
\hline Individual labor activity & 124 & 3252 & 2437 \\
\hline Construction agents & 9 & 563 & 431 \\
\hline Industrial Clerks & 24 & 793 & 672 \\
\hline Military clerks & 6 & 420 & 542 \\
\hline Workers in foreign countries & 19 & 1087 & 1531 \\
\hline Others & 55 & 2467 & 3009 \\
\hline & 500 & 14259 & 15714 \\
\hline
\end{tabular}

Table 5: Classification of families by skill level and trade, their structure by purchases.

The results of Table 6 matrix family group on the head of the domestic the most demanding segment of teachers, businesspersons and builders, respectively. Cloakroom countries share in this segment of the analysis of the percentage of teachers in year 2012, the family wardrobe is $25 \%$, and $32 \%$ in 2014 , the family of entrepreneurs wardrobe $37 \%, 42 \%$, in the family of builders wardrobe is $16 \%, 30 \%$ is determined.

Oilier largest share in the structure of the family group, individual work to have been correct, and the share of this group (21\% in year 2012 and 32\% in year 2014) was low compared to other groups aching. Accordingly, this group formed in accordance with the order of Chinese ready-to-wear range. Farmers and military families' wardrobe China accounted for more than that. 
Citation: Ahmadovich HZ (2017) Panel Researching in Study of the Competitive Environment in Clothing Market. J Account Mark 6: 251. doi: 10.4172/2168-9601.1000251

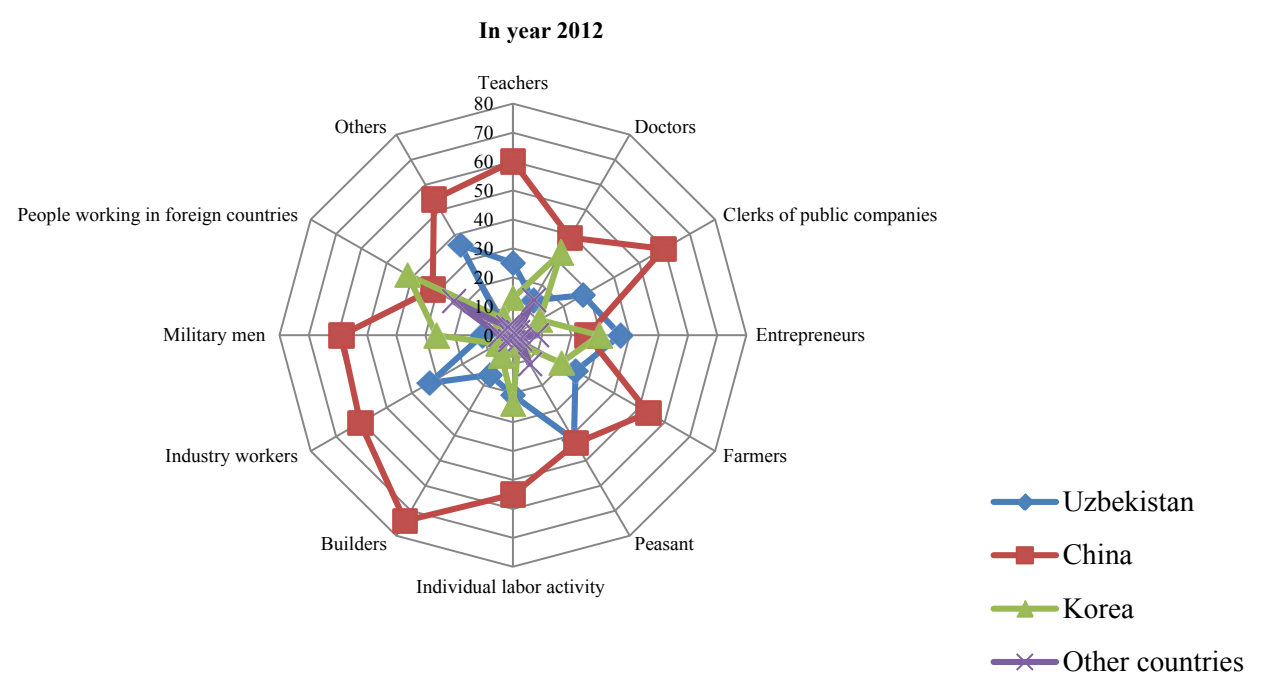

Figure 2: Share of competitors on profession of population

In year 2014

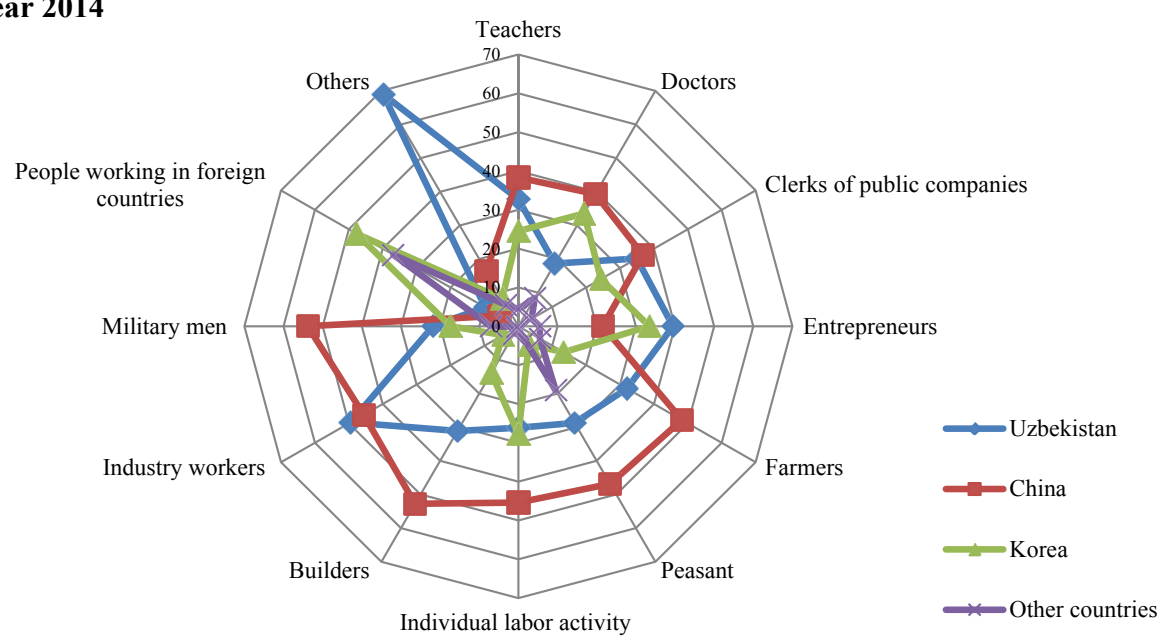

Figure 3: Share of competitors on profession of population.

\begin{tabular}{|c|c|c|c|c|c|c|c|}
\hline Segments & Connection price & Quality of & $\begin{array}{l}\text { Fashionable } \\
\text { compatibility }\end{array}$ & $\begin{array}{c}\text { Impact of } \\
\text { business activity }\end{array}$ & Personal hygiene & Other aspects & Total \\
\hline Teachers & $* * *$ & $* * *$ & $* * *$ & $* * *$ & * & ** & 15 \\
\hline Doctors & $* \star *$ & ** & * & * & $* * *$ & * & 11 \\
\hline $\begin{array}{l}\text { Employees of state } \\
\text { enterprises }\end{array}$ & * & $* * *$ & $* * *$ & $* \star *$ & * & * & 12 \\
\hline Businessman & * & $* * *$ & $* * *$ & $* \star \star$ & $* * *$ & $* *$ & 15 \\
\hline Farmers & $*$ & $* * *$ & * & * & * & * & 8 \\
\hline Farmers & $* * *$ & $* * *$ & * & ** & * & * & 11 \\
\hline Individual worker & $*$ & $* * *$ & * & * & * & $* * *$ & 10 \\
\hline Builders & ** & $* * *$ & * & $* \star *$ & $* * *$ & * & 14 \\
\hline Industrialists & * & $* * *$ & * & * & * & * & 8 \\
\hline Military & * & $* * *$ & * & * & $* * *$ & * & 9 \\
\hline Harris countries workers & * & $* * *$ & $* * *$ & * & * & * & 10 \\
\hline
\end{tabular}

***: Powerful effect; **: Secondary effects; *: Less affected; 0: Does not affect.

Table 6: Family members of the domestic segment of the matrix of factors that influence the formation of the wardrobe.

Change in composition of ready-to-wear range of families and their competitive strategies of enterprises through the analysis of countries' share of production range is set to start working on the issue of the formation of matter. Accordingly, consumer's wardrobe emerging assortment includes the share of domestically produced products. For each segment assortment of wardrobe structure to determine the 


\begin{tabular}{|c|c|c|c|c|c|c|c|c|c|}
\hline \multirow{2}{*}{ Consumer segments } & \multicolumn{9}{|c|}{ Indirect competition (\%) } \\
\hline & Years & \multicolumn{2}{|c|}{ Uzbekistan } & \multicolumn{2}{|c|}{ China } & \multicolumn{2}{|c|}{ Turkey } & \multicolumn{2}{|c|}{ Other } \\
\hline \multirow{2}{*}{ Women's wardrobes } & 2012 & $x$ & 16 & 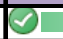 & 45 & (D) & 32 & (x) & 6 \\
\hline & 2014 & $\bar{x}$ & 13 & 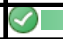 & 38 & $\sigma$ & 39 & 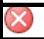 & 11 \\
\hline \multirow{2}{*}{ Men wardrobes } & 2012 & $(\sigma)$ & 50 & (D) & 31 & ( & 14 & $\bar{x}$ & 4 \\
\hline & 2014 & ( & 63 & $x$ & 17 & $\bar{x}$ & 8 & (x) & 12 \\
\hline \multirow{2}{*}{ Students wardrobes } & 2012 & 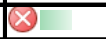 & 16 & $\nabla$ & 69 & $\bar{x}$ & 12 & 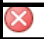 & 3 \\
\hline & 2014 & (1) & 34 & $\sigma$ & 47 & $\bar{x}$ & 11 & ( & 9 \\
\hline \multirow{2}{*}{$\begin{array}{l}\text { Goup of infant school } \\
\text { attenders' wardrobes }\end{array}$} & 2012 & $x$ & 10 & 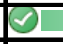 & 56 & $x$ & 24 & $x$ & 10 \\
\hline & 2014 & (C) & 31 & (P) & 25 & 0 & 37 & $\otimes$ & 6 \\
\hline \multirow{2}{*}{ Total } & 2012 & $x$ & 20 & $\sigma$ & 51 & (1) & 22 & $x$ & 6 \\
\hline & 2014 & (ए) & 32 & D & 35 & (D) & 24 & (x) & 9 \\
\hline
\end{tabular}

Table 7: The share of participants in the wardrobe of the consumer segment.

share of the competing countries. Assortment composition in order to further the analysis of children, students, men and women of the segments that purpose.

Consumer's ready-to-wear clothes of defined segments of the market share in the state are reflected in Table 7. According to table results in women's wardrobe the share of those produced in Uzbekistan decreased to $13 \%$ in year 2014 against 16\% in 2012, and the share of Chinese production decreased to $38 \%$ against $45 \%$. The purchase of dress made in Turkey and in other countries has increased.

In the formation of men's wardrobe, it have been achieved to increase the share of Uzbekistan made products grew from $50-63 \%$ and has been trying to oust the competitors out of market.

Big changes have made in students' wardrobe as the share of Uzbek made uniform increased from 10-31\%. In trainees' wardrobe, Uzbekistan made garment grew almost by 3 times. Research outcomes show that as the result of the strategy of excluding the Chinese goods out of market the share of Uzbekistan made garments increased from 20$32 \%$ in year 2012-2014. Ready-made clothes produced in Uzbekistan are competing on an equal footing with Chinese and Turkish products (32\%, 35\%, 24\% respectively). On analyses results base it has been offering to create the strategy of protecting household clothing market of Uzbekistan from competitors.

In order to make easy the analyses of change in the range of consumer purchases and the share of the producing countries appropriate settings have been made in Table 6, A market share matrix have create according to appropriate settings. Considering that the analyses has been made for the end of two years, the changes of procurement structure in this period for each assortment by settings of matrix in table (red $(x)$, yellow $(!)$ and blue $(\sqrt{ })$ ) offered the following strategy of managing the assortment. There are possibilities to perform for each garment producing companies' settings suitable for matrix. For each setting the following strategies is performed.

In the appropriate levels of development strategies (the red (x) mark), for the companies offering a range of business strategic objectives took place to find its place and enter in the domestic market. It has been outlined what directions to pay attention to for entering the domestic market.

First stage development strategy is recommended for women's readymade clothing manufacturing market subjects. In this range, the enterprises operating in market should pay attention to the following in formation of own assortment strategy: widening the technical-economic capacity of company, create new models, to pay more attention to innovations, forming the modernization programs, diversification of product.
Action strategies (yellow (!) mark) suit market subjects working in students and trainees segment market. This strategy has mainly considered pushing out the foreign assortment from domestic market strategy. Accordingly, in the purposes of this strategy it has been paid attention to the use of effective methods of association with consumers. The first stage of this strategy have must is applied for the main assortment of students and children. The main attention is given to aspects of mechanisms for the effective use of marketing communications. It creates the opportunity to increase market share in the competition especially in applying the branding opportunities for students' assortments. Development strategy is aimed to drive imported goods completely out of market and maintain the share of enterprises and will continue to rise in status.

At the same time, the expansion of the range of the assortment of goods as much as possible, diversification, concentration, increase the cost of marketing, raising the fashion design up to international level are considered to be the main factors of development.

Conservation Strategies (blue color $(\sqrt{ })$ mark) levels, respectively, reflects to cover the domestic market with domestic products fully and the sequence of actions aimed to preserve this share and combines criteria of formation criteria of development strategies for foreign markets. Conversation strategy if specific for subjects operating in market with men's ready-to-wear strategy. They must concentrate the main activity of company on maintaining existing customers. Competitiveness should increase the opportunities of access to foreign markets, connection of companies operating in this level of matrix to the single link base and using international marketing strategies effectively.

\section{Conclusion}

Enterprises should increase the effectiveness of relation channels with consumers for maintaining the existing market, increasing the advertising costs, bring all producers into single unit base, increase the attractiveness of brand, determine the strategic objectives of development in international markets and use the potential of internal market fully, access the services of international organizations, trading houses, brokerage agencies, international design and fashion, consulting centers, engineering, obtaining international quality certificates, detailed study of foreign markets and spend funds for marketing researches in this regard in organized basis.

\section{References}

1. Cline WR. The future of world trade in textiles and apparel.

2. Doeringer $P$, Crean $S$ (2006). Can fast fashion save the U.S. apparel industry? Socio-Economic Review 4: 353-377. 
Citation: Ahmadovich HZ (2017) Panel Researching in Study of the Competitive Environment in Clothing Market. J Account Mark 6: 251. doi: 10.4172/2168-9601.1000251

3. Dickerson KG (1999) Textiles and apparel in the global economy. Prentice Hall.

4. Nordås HK (2004) The global textile and clothing industry post the agreement on textiles and clothing. WTO Discussion Paper.

5. Verma S (2002) Export competitiveness of Indian textile and garment industry. Indian Council for Research on International Economic Relations, Working Paper, pp: 94.

6. Lee $J(2013)$ Competitiveness of textile and apparel industries in the United States and Japan.

7. Evgeniev E (2006) Industrial and firm upgrading in the European periphery (Doctoral dissertation, Institute of Economics, Hungarian Academy of Sciences, Hungary).

8. Stacura Al (2009) Formation and development of the competitiveness of the entrepreneurial structure in the textile products market. Thesis for the degree of Candidate of Economic Sciences, St. Petersburg.

9. Filyukov YK (2010) Development of a mechanism for managing the competitiveness of light industry enterprises on the basis of improving methodological approaches to its assessment and regulation. Theses for the degree of Candidate of Economic Sciences, St. Petersburg.

10. Prazyan IV (2007) Marketing obezpechenie competitiveness of the enterprises of light industry. Theses for the degree of Candidate of Economic Sciences. Volgograd.
11. Fradina TI (2010) Methodology and methods for managing the competitiveness of light industry enterprises in the context of economic globalization. Thesis for the degree of Doctor of Economic Sciences. Saint-Petersburg.

12. Genova S (2006) Optimization of the process of planning the range of products within the marketing activities of the enterprise. Specialty: 08.00.06. - Marketing Logistics. Thesis for the degree of Doctor of Economic Sciences. Chisinau.

13. Xiajun A, Dorothe'e H (2012) Assortment planning for vertically differentiated products. Production and Operations Management Society 21: 253-275.

14. Dass M, Kumar P, Peev PP (2013) Brand vulnerability to product assortments and prices. Journal of Marketing Management 29: 735-754

15. Burdenko EV (2016) Industrial policy and models of supply and demand for finished products of light industry. Journal of Science and Practice 4: 24

16. Malhotra NK (2007) Marketing researches: Practical guidance, ( $4^{\text {th }}$ edn.), pp: 145

17. Manual for conducting interviews with selected households. Statistic Committee of Republic of Uzbekistan.

18. Johnson JS (2016) Improving online panel data usage in sales research Journal of Personal Selling \& Sales Management 36: 74-85.

19. Lundy JD (2012) Measuring annual change in household wealth with the Consumer Expenditure Survey. Monthly Lab. Rev 135: 34. 